\title{
The impact of the cognitive apprenticeship style use on academic achievement in the health education curriculum
}

"Dr. / Eman Ahmed Maher

Introduction and research problem:

The world is witnessing an IT revolution in this century in all areas of knowledge, and this enormous revolution makes it imperative for educational institutions to reconsider the foundations of the selection, Planning and construction of the curriculum and methods of dealing with the knowledge, in terms of teaching methods, style of students and teachers deal with it.

And constructivist theory is one of the cognitive theories that had occupied the attention of researchers in the field of scientific research for many years,

And grew out of the ideas and methods of teaching varied methods. (10:23)

The discipleship of cognitive apprenticeship approach educationally, is considered a model of education, including offer of practical steps for the application of realism cognitive theory,

Where it works to engage the learners in work tasks within a real learning environment، And noteworthy

That the application of cognitive style apprenticeship is not an act to be implemented in a piecemeal fashion, and making sequential and gradual steps to achieve the goal of knowledge

This is what sparked the motivation about

\footnotetext{
* Assistant in the Department of Curriculum and Instruction professor of Physical Education, Eaculty of Physical Education for Girls (Helwan University)

Assiut Journal For Sport Science Arts
} 
choosing the subject of research as the material (Healthy culture) which inherently interesting, because it's teaching the students bodily information and useful in modifying habits behavioral, but the reality proved that taught like any decision of my college still depends on the lecture and memorization, and of the most prominent disadvantages negative students and the abolition of the incentive, and save information and replicated without understanding.

While the teaching style using cognitive apprenticeship, which depends on the style of selfguided discovery and the application depends on the participation of students positively effective in building experience.

\section{Aim of the research:}

The research aims to identify the impact of the use of cognitive style apprenticeship on the academic achievement of the health education curriculum.

\section{Research hypotheses-:}

There are statistically significant between the average level students the control group differences (which studied the traditional way), and the average level students of experimental Group studied using (cognitive apprenticeship method) in academic achievement with the subject of health education in the post test.. Experimental Group

\section{Terms which used:}

Cognitive apprenticeship, academic achievement

\section{Find measures:}

\section{Research Methodology:}

Researcher relied on the experimental method and that the two groups, the control group and the other experimental.

The research community:

Consists of all students the first year, Faculty of 
Education, University of King Faisal. Enrolled academic year of 2014 and their number (270) students.

\section{The research sample:}

The research sample included on (60) Student, were selected from a random way the research community, and that the rate of (30) students (as a control), and (30) students (as a group trial،)

Adjust the variables of the sample individuals:

It has operations parity for members of the experimental group and control group for the following variables as follows:

\section{Table (1)}

Significant differences between the two groups (control group - experimental) In variables (age - length - weight)

\begin{tabular}{c|c|c|c|c|c|c}
\hline \hline \multirow{2}{*}{$\begin{array}{c}\text { Value } \\
(\mathbf{T})\end{array}$} & \multicolumn{2}{|c|}{$\begin{array}{c}\text { The experimental } \\
\text { group } \mathbf{n}=\mathbf{3 0}\end{array}$} & \multicolumn{2}{c|}{$\begin{array}{c}\text { The control } \\
\text { group n = 30 }\end{array}$} & \multirow{2}{*}{ Variables } & \multirow{2}{*}{ S. } \\
\cline { 2 - 5 } & $\mathrm{y}$ & $\mathrm{x}$ & $\mathrm{y}$ & $\mathrm{x}$ & & \\
\hline \hline 0.569 & 0.421 & 21.194 & 0.456 & 21.256 & Age & 1 \\
\hline 0.714 & 2.327 & 164.327 & 1.765 & 164.215 & Height & 2 \\
\hline 0.706 & 2.126 & 60.322 & 1.326 & 60.134 & Weight & 3 \\
\hline \hline
\end{tabular}

Value $(\mathrm{T})$ Driven at the abstract level $(0.05)=1.984$

It's seen from the above table (1) that

there are no statistically significant differences between the control group and the experimental group in each of the age, height and weight differences, indicating the homogeneity of the research sample.
Research procedures and tools:

-Planning teaching style using cognitive apprenticeship:

-Preparation Teacher's

Guide

-Achievement test

Exploratory experience: 
- In order to check the picture for the final test grades, determine the

\section{Table (2)}

Ease, difficulty and discrimination of the group exploratory transaction values $(\mathbf{N}=15)$

\begin{tabular}{c|c|c|c|c|c|c|c}
\hline \hline $\begin{array}{c}\text { Discrim } \\
\text { ination }\end{array}$ & Difficulty & Easy & s. & $\begin{array}{c}\text { Discrim } \\
\text { ination }\end{array}$ & Difficulty & Easy & s. \\
\hline \hline 0.13 & 0.87 & 0.13 & 16 & 0.06 & 0,93 & 0.07 & 1 \\
\hline 0.35 & 0.67 & 0.33 & 17 & 0.19 & 0.80 & 0.20 & 2 \\
\hline 0.49 & 0.53 & 0.47 & 18 & 0.13 & 0.87 & 0.13 & 3 \\
\hline 0.35 & 0.67 & 0.33 & 19 & 0.13 & 0.87 & 0.13 & 4 \\
\hline 0.49 & 0.53 & 0.47 & 20 & 0.35 & 0.67 & 0.33 & 5 \\
\hline 0.55 & 0.47 & 0.53 & 21 & 0.35 & 0.67 & 0.33 & 6 \\
\hline 0.49 & 0.53 & 0.47 & 22 & 0.06 & 0.93 & 0.07 & 7 \\
\hline 0.19 & 0.80 & 0.20 & 23 & 0.49 & 0.53 & 0.47 & 8 \\
\hline 0.19 & 0.80 & 0.20 & 24 & 0.55 & 0.47 & 0.53 & 9 \\
\hline 0.35 & 0.67 & 0.33 & 25 & 0.55 & 0.47 & 0.53 & 10 \\
\hline 0.49 & 0.53 & 0.47 & 26 & 0.19 & 0.80 & 0.20 & 11 \\
\hline 0.06 & 0,93 & 0.07 & 27 & 0.62 & 0.40 & 0.60 & 12 \\
\hline 0.55 & 0.47 & 0.53 & 28 & 0.62 & 0.40 & 0.60 & 13 \\
\hline 0.35 & 0.67 & 0.33 & 29 & 0.49 & 0.53 & 0.47 & 14 \\
\hline 0.49 & 0.53 & 0.47 & 30 & 0.13 & 0.87 & 0.13 & 15 \\
\hline \hline
\end{tabular}

\section{Trust test- :}

There is an agreement between experts about the validity of the test application

\section{Stability testing- :}

Richardson Coder test equivalent was calculated answer to questions from the test time 
Table (3)

Consistency between the first application and the second application in final test account The group's exploratory

using Pearson's correlation coefficient ) $\mathbf{N}=15$ )

\begin{tabular}{c|c|c|c|c}
\hline \hline \multirow{2}{*}{ Value (r) } & \multicolumn{2}{|c|}{$\begin{array}{c}\text { The second } \\
\text { application }\end{array}$} & \multicolumn{2}{c}{$\begin{array}{c}\text { The first } \\
\text { application }\end{array}$} \\
\cline { 2 - 5 } & $\mathbf{y}$ & $\mathbf{x} /$ & $\mathbf{y}$ & $\mathbf{x} /$ \\
\hline \hline $0.897^{*}$ & 2.511 & 27.95 & 2.756 & 26.69 \\
\hline \hline
\end{tabular}

Value (t) Tabulated at the abstract level $(0.05=)$

The previous table shows (3) that there is a positive correlation between the $\mathrm{D}$ the first application and the second application, which shows the stability of the responses of the students on the test results.

\section{Application search experience:}

Basic experiment was performed according to plan for the time units educational decision culture, health and so the rate of (12 weeks - a weekly lecture) to the content of the Platform 6 instructional units

Posterior measurements- :
The researcher tested after each lecture experimental and control group (interface tests)

Then the researcher to conduct a final test on the course units of the control and experimental groups on 01.08.2015, and compare the results of control and experimental groups in the final exam

(end of the school year.)

Statically treatments -

In order to achieve the goal

of Find researcher used Arithmetic mean (-standard deviation -value of the significance differences Analysis of variance - 
significant coefficient - ease and difficulty coefficient.) Presentation discussion and and interpretation of the results:

First: Results:

-Interface tests of the Scholastic units (6 units)

-The final test (30 degrees.)

Table (4)

Statistical description of the control group in the six chapters scheduled tests The ultimate test $(N=60)$

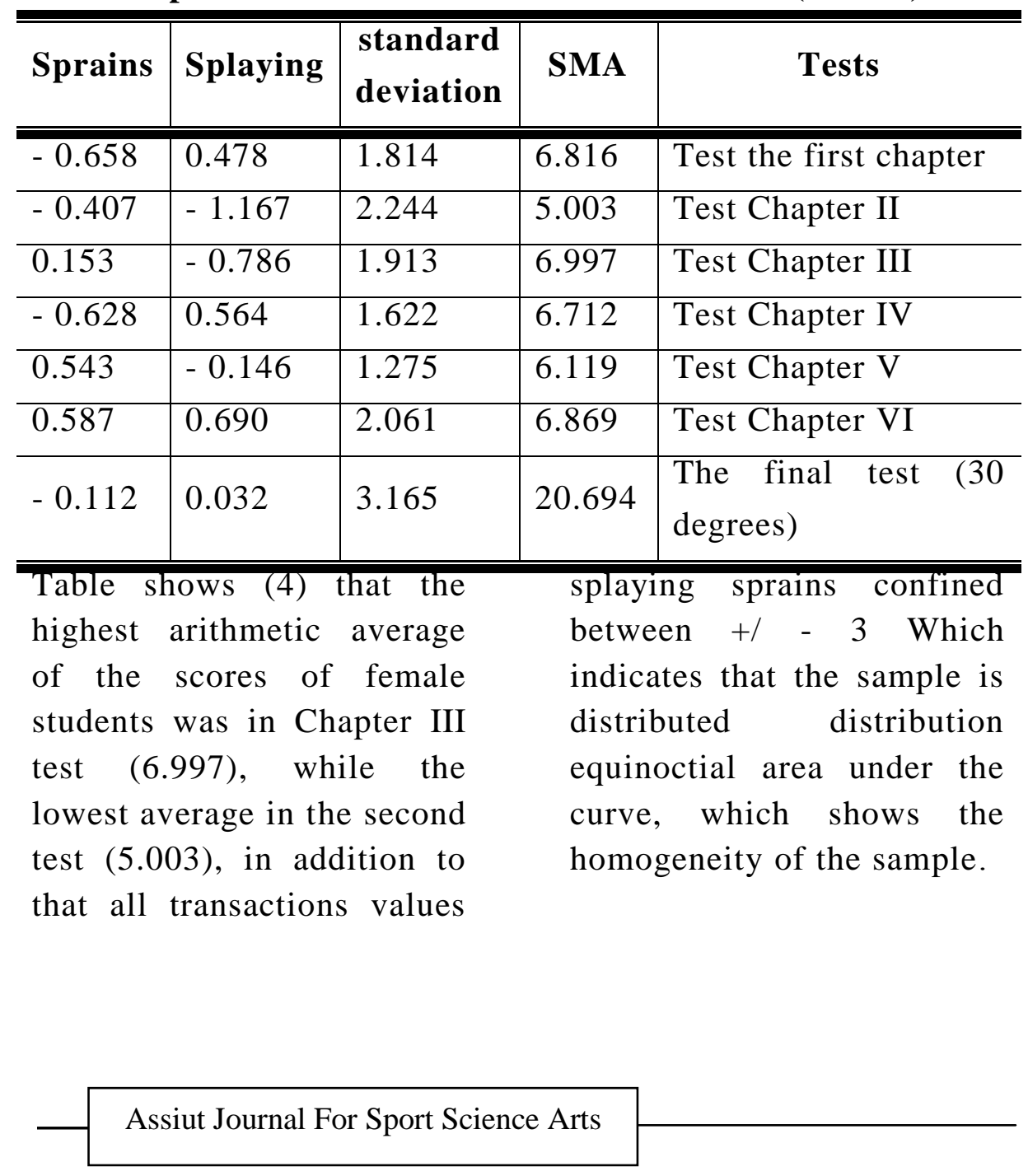


Table (5)

Statistical characterization experimental group in the six classes scheduled tests The ultimate test $(N=60)$

\begin{tabular}{c|c|c|c|l}
\hline \hline Sprains & Splaying & $\begin{array}{c}\text { standard } \\
\text { deviation }\end{array}$ & SMA & \multicolumn{1}{|c}{ tests } \\
\hline \hline-0.234 & -0.796 & 1.721 & 8.956 & Test the first chapter \\
\hline-0.495 & 0.288 & 1.007 & 7.799 & Test Chapter II \\
\hline-0.686 & -0.312 & 1.264 & 8.994 & Test Chapter III \\
\hline-0.237 & -0.824 & 1.132 & 9.000 & Test Chapter IV \\
\hline-0.345 & -1.229 & 0.987 & 8.476 & Test Chapter V \\
\hline-0.489 & -1.214 & 1.334 & 9.121 & Test Chapter VI \\
\hline-0.486 & 0.248 & 2.146 & 27.887 & The final test (30 degrees) \\
\hline \hline
\end{tabular}

Table (5) shows that the splaying sprains confined highest arithmetic average between +/-3 which of the scores of female students was in Chapter VI test (9.121), while the lowest average in the second test (7.799), in addition to indicates that the sample is distributed distribution equinoctial area under the curve, which shows the homogeneity of the sample. that all transactions values

Table (6)

Significant statistical differences between the control group and the experimental classes in the six scheduled tests

\begin{tabular}{c|c|c|c|c|c|c}
\hline \hline \multirow{2}{*}{ Value (T) } & \multicolumn{2}{|c|}{$\begin{array}{c}\text { The experimental } \\
\text { group N = 60 }\end{array}$} & \multicolumn{2}{|c|}{$\begin{array}{c}\text { The control group } \\
\text { N= 60 }\end{array}$} & \multirow{2}{*}{ Maps } & s \\
\cline { 2 - 6 } & $\mathrm{y}$ & $\mathrm{x} /$ & $\mathrm{y}$ & $\mathrm{x}$ & & \\
\hline$* 8.496$ & 1.721 & 8.956 & 1.814 & 6.816 & chapter One & 1 \\
\hline$* 13.783$ & 1.007 & 7.799 & 2.244 & 5.003 & Chapter II & 2 \\
\hline$* 7.244$ & 1.264 & 8.994 & 1.913 & 6.997 & Chapter III & 3 \\
\hline$* 10.214$ & 1.132 & 9.000 & 1.622 & 6.712 & Chapter IV & 4 \\
\hline$* 12.628$ & 0.987 & 8.476 & 1.275 & 6.119 & Chapter V & 5 \\
\hline$* 9.783$ & 1.334 & 9.121 & 2.061 & 6.869 & Chapter VI & 6 \\
\hline \hline
\end{tabular}

Value $(\mathrm{T})$ Driven at the abstract level $(0.05)=1.984$

Assiut Journal For Sport Science Arts 
The table shows (6)

on the existence of statistically significant differences between the experimental group in all seasons of the six tests scheduled for the control group and the experimental group.

Table (7)

Significant statistical differences between the control group and the experimentalIn final test (30 degrees) with decision

\begin{tabular}{c|c|c|c|c|c}
\hline \hline \multirow{2}{*}{$\begin{array}{c}\text { Value } \\
(\mathbf{T})\end{array}$} & \multicolumn{2}{|c|}{$\begin{array}{c}\text { The } \\
\text { experimental } \\
\text { group N = 60 }\end{array}$} & \multicolumn{2}{c|}{$\begin{array}{c}\text { The control } \\
\text { group N = 60 }\end{array}$} & \multirow{2}{*}{ Maps } \\
\cline { 2 - 5 } & $\mathbf{y}$ & $\mathbf{x}$ & $\mathbf{y}$ & $\mathbf{x}$ & \\
\hline \hline $\begin{array}{l}14.211 \\
*\end{array}$ & 2.146 & 27.887 & 3.165 & 20.694 & $\begin{array}{l}\text { The final test of the seven } \\
\text { maps (30) degree }\end{array}$ \\
\hline \hline
\end{tabular}

Value (T) Driven at the abstract level $(0.05)=1.984$ The table shows (7) The table also shows (5) and no statistically that the highest arithmetic significant differences average of the scores of between the control group and the experimental group in final test article for the experimental group.

Second, discuss and interpret the results:

The results (Table 4) that the highest arithmetic average of the scores of female students was in Chapter III test (6.997), while the lowest average in the second tests (5.003.) female students was in Chapter VI test (9.121), while the lowest average in the second tests (7.799)

The table shows the results (6) that there are significant differences between the control group and the experimental group in all seasons of the six tests of material differences in favor of the experimental group.

Assiut Journal For Sport Science Arts 
As it turns out the results table (7), there are significant differences between the control group and the experimental group in the final test of the material for the experimental group differences.

And agree the results of the current study with the results of each of the studies (Soha Mahmoud Sabri 2012 - Atef Mohammed Saeed 2010 - Chan Chan, G 2009) that there are significant differences Betwen experimental group and the control group for the experimental group 'where The results of the study "Soha Mahmoud Sabri 2012 "indicates that there are significant differences to the averages of the collection experimental group students who learned using cognitive apprenticeship method for the experimental group, while the results of a study" Atef Mohammed Saeed
2010 "referred to the superiority experimental group studied using strategies Reciprocal Teaching and cognitive apprenticeship is due this superiority to the nature of the experimental treatment, where helped the use of strategies to available of active participation to know themselves, as it help for positive interaction between teacher and student, and students and each other at a height level of achievement they have 'noted the results of the study of "Chan Chan, G 2009" superiority of experimental group where the use of the cognitive apprenticeship them more interesting to learning the language than before, and advanced academic achievements, not only in reading, but in the other language skills, as demonstrated excellence in testing a remarkable achievement, as well as in 
their ability to speak and toning and mother tongue .

While the results of the current study are consistent with the results of each of the studies (Gautier and Solomon 2011 - Susan Mahmoud Saiad Abu thrown away in 2011 - Osaaa Hamid Mahmoud, 2010) that the use of cognitive apprenticeship approach has a positive effect in the acquisition of knowledge and the use of mental processes' where The results of the study "Osaaa 2010 "to the existence of the proposed educational for other programmer in levels of knowledge and performance piece, at the significance level (0.05) due program content for cognitive apprenticeship as a model to teach, and how employed in educational operation through activation the presence of statistically significant differences between the two groups in favor of experimental group , to suggesting of the two strategies' while The results of the study "Susan 2011" to the superiority of the male and female at the level (0.05) in acquiring the ability to solve problems in the science curriculum where it is due to the use of cognitive apprenticeship style 'while the results of the study agreed with them, "Gautier and Solomon 2011" in success -oriented knowledge (cognitive apprenticeship method) and that education was useful in setting goals, and that the shares and dynamically in the acquisition of knowledge and the use of mental processes.

\section{Research findings:}

In light of the objective of the research and verification imposed in the light of possible statistical treatments used to arrive at the most important 
researcher the following conclusions:

The highest arithmetic average of the grades students in the control group was Chapter III test (6.997), while the lowest average in the second tests (5.003)

2 .The highest arithmetic average of the grades students of the experimental group was in Chapter VI test (9.121), while the lowest average in the second tests (7.799.)

3 .There are significant differences between the control group and the experimental group in all six chapters' curriculum tests for the experimental group differences.

4 .There are statistically significant differences between the control group and the experimental group in the final test with the decision in favor of the experimental group.

Find recommendations:
Based on the results of the study were the following recommendations put

1 Researcher Curriculum officials and creators recommends adopting the style of cognitive apprenticeship in the curricula because of its positive impact on learning and the collection of the students think they have urged

2 researchers recommend more research on the cognitive style of apprenticeship and its application in teaching other decisions on multiple seminars and stages.

\section{List of references}

First: The Arabic references

\section{Aseaa Hamid Mohammed:}

"Following the educational program proposed using active learning strategies and direct training in the ability to recruit cognitive apprenticeship model in teaching the Student 
Teachers", published scientific research, Faculty of Education Journal, Part II, No. 74, Arab Republic of Egypt (2010.)

\section{2 .Hassan Hussein Zighton:} "teaching strategies contemporary vision of the ways of teaching and learning, the world of books for printing and publishing (2012).

\section{3 .Jaber Abdul Hamid:} Teaching and learning strategies ", Volume I, Dar Al Arab Thought for printing and publishing, Arab Republic of Egypt (2008).

\section{4 .Soha Mahmoud Sabri:}

"The effect of using the style of cognitive apprenticeship in the teaching of science to collect his request tenth grade core and the development of scientific thinking they have," Unpublished Master Search, Najah National University,
Graduate School, Nablus, Palestine (2012(

\section{5 .Susan Mahmoud Said:}

"Following the style of teaching is based on cognitive apprenticeship in the teaching of science to his request fifth grade core to the development of the ability to solve problems", a scientific research publication, Journal of Educational Science, Vol. 38, Supplement 5, Deanship of Scientific Research, the University of Jordan (2011)

\section{Mohammed Atef Said} Abdullah: "The effect of using interactive teaching strategies and cognitive apprenticeship in the teaching of history to the collection and development of historical thinking in the first grade secondary students" Scientific research publication, Journal of Society for Educational Social Studies, the Arab Republic of Egypt (2010( 
7 .Mubarak Salem, Yahya

Mohammed: apprenticeship program", published scientific, management of public Education in Riyadh, the Department of the Gifted, Saudi Arabia (2010)

8 .Mahmoud Ayesh

Zighton: "Constructivist theory and strategies for teaching science", the first release, Sunrise House for Publishing and Distribution, Amman (2007)

Second: the English references

10-Bieniek, V : "Implementation of Cognitive Apprenticeship model of student programming and perception of problem Solving ability $: \mathrm{Ab}$ Exploratory study Retrieved, Journal of collage students education -New Orleans (2008)

\section{1-Brandt.B, Framer.J,} andBuckmaster., A: " Cognitive Apprenticeship approach to helping adult $\mathrm{s}$ learn "New direction for adult and continuing education ,Journal of teacher education ,34 (2), 29-24 (2010)

\section{1- Cash .J,Beherman .M,} Stadt.R and Daniels.S:

"Effectiveness of cognative Apprenticeship and Instructional Methods in collage automotive technology classrooms" ,journal of industrial teacher $\begin{array}{lll}\text { education } \quad 34 & \text { (2):29-49 }\end{array}$ (1997).

\section{2- Edmondson .R :]}

"Investigating the effectiveness of Telepresenc- Enabled Cognitive Apprenticeship model of teacher Professional Development doctoral dissertation spectrum education American Education Research Journal (2009).

\section{3- Gauties, $C$ and} Solomon .R :"A preliminary study of student asking Question for Inquiry-Based Climate Model Experiments Journal of Geosciences education ,54 (4) 422-427 (2011) 


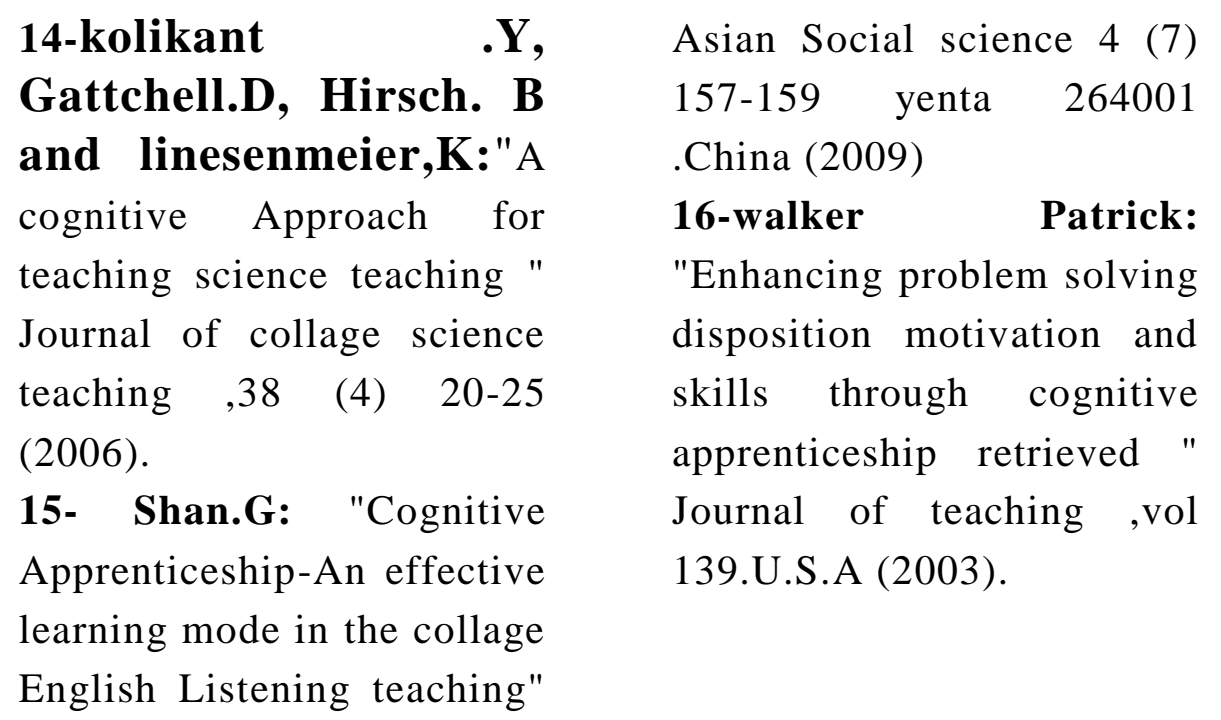

